\title{
Tracer Study: University of Bohol, Bachelor in Elementary Education, 2009-2012
}

\author{
LIBYA T. PAMARAN \\ ORCID No.: 0000-0001-7632-4173 \\ mslibyapamaran@gmail.com \\ LUMIN T. PAMARAN \\ vpluminpamaran@gmail.com \\ ORCID No.: 0000-0001-6618-5659
}

\begin{abstract}
Alumni tracer study is one of the best measures on how graduates benefit from the programs and courses they completed to become successful professionals and worthy members of the society. The study used descriptive, purposive method with the aid of a survey- questionnaire to trace the Bachelor of Elementary Education graduates of the University of Bohol. Results showed that majority was employed related to their degree completed, and majority, as well, passed the licensure examination. As to the usefulness of the curriculum, the graduate- respondents found most of the subjects offered very useful. As to personal skills, interpersonal, intellectual and specific skills areas, the graduaterespondents rated all items as Extremely Important, as to its importance to career success, they rated the same items as Very Good as to the extent that they possessed such skills. Findings of this study aspired to provide insights for the stakeholders within and outside the university in refining all the more their development agenda to increase decent and productive employment and job opportunities for graduates.
\end{abstract}

\section{KEYWORDS}

Tracer Study, curriculum development, descriptive-purposive method, Tagbilaran City, Philippines. 


\section{INTRODUCTION}

As a premier university committed towards enabling a person to live a worthy, fulfilling and abundant life, the University of Bohol is interested in following the various journeys of its graduates to find out how they fare in the industry. It is crucial for tertiary institutions to understand the synergy between course structures and the job market. It can be done by updating itself with the demands of the work environment through the essential feedback from alumni graduates. In order to address possible deficits in a given educational program and to assist in better planning at both the institutional and national levels, there is a need to assess if academic provisions are more closely aligned with the demands of the economy.

This alumni tracer study was conducted in collaboration with the University Research Center.

This research zoomed into graduates of the University of Bohol Bachelor of Elementary Education to ascertain whether, the curriculum of the college prepare them to become successful teachers and worthy members of the society. This was further conducted to ascertain whether they were able to develop their personal, interpersonal and intellectual competencies and skills honed in the college which are needed to pass the licensure examination for teachers, land a teaching job and meet the needs of the academic industry. This study is very timely and relevant for two reasons: 1 ) the University of Bohol is currently working on its accreditation status under PAASCU, and other accrediting bodies; and 2) the Department of Education (DepEd) continually conduct evaluation and selection of competent teacher applicants. It is hoped that whatever findings which may surface from this modest endeavor shall form the basis to institute the necessary reforms and policies to ensure that UB Teachers College and its graduates are prepared to meet the challenges of the 21 st century.

As to the theoretical underpinnings, the study made use of the human capital model (Mincer 1958; Schultz 1961) which provided logical explanation of the schools' functions in developing knowledge, competencies and skills on students to prepare them for better outcomes (Quiggin 1999).The human capital theory is the most sensible theory that captures the inclusion of policies in education and development. As pointed out by Shultz (1971), the theory relied on the assumption that formal education played a significant role and highly necessary to augment the production capacity of the population. It further elaborated that an educated population is a more productive population. It emphasized that workers' productivity and efficiency are increased by increasing the level of stock 
of knowledge of economically productive human capability which is a byplay of innate abilities and investment in human beings (Olaniyan \& Okemakinde 2008).

Yorke (2006) raised the following key points: 1) Employability is a set of achievements - skills, understandings and personal attributes - that makes graduates more likely to gain employment and be successful in their chosen occupation, which benefits themselves, the workforce, the community and the economy; 2) Employability is not the same as finding employment but is more about the capacity of the graduate to function in a work environment; 3) It is necessary to develop generic skills, such as teamwork, communication and organizational skills while also developing subject specific skills such as numeracy; 4) It is necessary to embed "employability" into the curriculum; and 5) With all things being equal, the more employable graduates should be quicker to settle into graduate jobs.

As emphasized by Yorke 2006, a set of achievements - skills, understandings and personal attributes comprised the set of achievements that enables graduates increase their chances to be employed and reap success in their fields of work. This will be beneficial for themselves, the workforce, the community and the economy (Pegg 2012).

The Career EDGE model supported the above-mentioned concept but shares a more holistic approach to curriculum design by incorporating five key components at the lower tier of the model represented by the mnemonic "Career EDGE": Career, Experience, Degree Subject, Knowledge, Skills and Understanding, Generic Skills and Emotional Intelligence. Later, the Career EDGE model was extended to consider issues around implementation and links with the growing enterprise agenda (Dacre-Pool and Sewell, 2007 and 2010).

Having recognized the excellent work of model builders, the issue of implementation and embedding of employability in the curriculum really boils down to what Watts (2006) published in his article Career Development Learning and Employability, "If career development learning programs are to continue to grow and develop, the nature of career services within higher education and their relationships with teaching departments need to be further reframed. The intellectual foundations of career development learning also need to be strengthened."

On Linkage and Employment. A definition of social capital (Burt 1992, Granovetter, 1995; Portes, 1998) as the relationships among people in a social group upon wherein the exchange of information, influence, or opportunity may transpire among them (Parks-Yancy 2006). Social capital is about building and establishing networks with people in one's field of study. Brinton (2000) suggests 
that there are two types: the private social capital and the institutional social capital. In private social capital, the individual has access through his or her personal networks whereas in institutional social capital the individual has access by virtue of belonging to a particular organization like an alumni association or professional organization. The contention was that if a graduate is outgoing and open, then he/she may be able to establish social contacts whereas others who are reserved and unable to easily communicate possibly due to their own inhibitions, may find it difficult to build up their own social capital.

On the global perspective, in 2007 the World Bank and UNESCO established a partnership that launched the Global Initiative for Quality Assurance Capacity (GIQAC) to support the evolution of quality assurance in higher education in developing countries and countries-in-transition by facilitating and advancing the efforts of its participating inter-regional and regional quality assurance networks (Altbach et al. 2009).

The concern for quality in the Philippine Higher Education is enunciated in the Section 1 of Article 14 of the 1987 Philippines Constitution which provides that "the State shall protect and promote the right of all citizens to quality education at all levels." The enactment of Republic Act 7722, otherwise known as the Higher Education Act of 1994 created the Commission on Higher Education (CHED) and directed it to promote and support higher education in the country. It further mandates CHED to monitor and evaluate performance of programs and institutions of higher learning.

In accordance with the pertinent provisions of Republic Act 7722 and for the purpose of rationalizing the undergraduate teacher education in the country to keep pace with the demands of global competitiveness, CHED Memorandum Order No. 30 series of 2004, otherwise known as the "Revised Policies and Standards for Undergraduate Teacher Education Curriculum" was adopted and promulgated by the Commission.

CHED Memorandum Order No. 01 series of 2005 - Revised Policies and Guidelines on Voluntary Accreditation in Aid of Quality and Excellence in Higher Education defined Accreditation as a process for assessing and upgrading the educational quality of higher education institutions and programs through self evaluation and peer judgment. It leads to the accreditation status by an accrediting agency and provides public recognition and information on educational quality. There are five (5) accrediting bodies for Higher Education in the Philippines: 1) Philippine Accrediting Association of Schools, Colleges and Universities (PAASCU), 2) Philippine Association of Colleges and Universities Commission on Accreditation (PACUCOA); 3) Association of Christian Schools, 
Colleges and Universities Accrediting Agency, Inc. (ACSCUAAI); 4) Accrediting Agency of Chartered Colleges and Universities of the Philippines (AACCUP); and 5) Association of Local Colleges and Universities Commission on Accreditation (ALCUCOA). All accrediting agencies are helping CHED in the promotion of quality improvement in the HEIS.

As this study focuses on the graduates of Bachelor in Elementary Education, it is significant to mention Republic Act No. 8190, otherwise known as the Localization Law, which grants priority to residents of the barangay, municipality or city where the school is located, in the appointment or assignment of classroom public school teachers.

There have been successful attempts to use tracer studies in the international area. In an effort to better understand the relevance and impact of the education offered by the UNESCO-IHE 2011, an Institute for Water Education conducted alumni tracer survey was conducted in 2011. The tracer survey consisted of 34 questions that addressed the performance of UNESCO-IHE graduates and aimed to gain a more detailed understanding of alumni career development and the relevance of the study programs. The study explored whether alumni benefited from UNESCO-IHE'S academic programs in genera, the changes alumni experienced in sector, job level and location, their further education and their professional network. The results proved to be helpful in continual improvement of the Institute's services for future generations of water professionals.

A Tracer Study of Science and Technology graduates of 2000 and 2001 was also conducted by the Management Information System Unit of Science and Technology Policy Research Division of the National Science Foundation of Sri Lanka. The analysis was mainly focused on gaining insight into the current employment status, sector of employment, absorption patterns and rates into the labor market and other useful issues. The results of the study served as basis of evaluation of degree course to meet the basic requirements of the industry for employment (Pathirage et al, 2003).

In 2008, Asian Institute of Technology conducted a tracer study targeting recent past graduates (2003 to mid 2005). The reason for choosing recent graduates was to look at the relevancy and effectiveness of the AIT degrees, courses, and research activities to the current changing context of the region. The second reason was based on the hypothesis that finding and contacting recent graduates would be easier so that response rate could be maximized. Other information obtained from the study shed light on the graduate's level of networking, gender awareness and social awareness. 
The Tertiary Education Commission (2011) in Mauritius conducted a graduate tracer study in view of updating their List of Indicative Priority Fields of Study (LIPFS) 2012/2013. The Graduate Tracer Study examines the relationship between tertiary education and the world of work. The results of the study has put into perspective the level of underemployment and unemployment amongst graduates as well as the extent of mismatch between their qualifications and employment. The findings provided ample data to assist in finalizing LIPFS. Moreover, the study reported that the higher unemployment and underemployment rates prevailing for those graduates cannot be attributed to any single reason, however, though some transitional factors would tend to affect them all, notwithstanding the current present global recession which is likely to impact adversely on the employment situation at home.

Salinas and Nillama (2011) conducted a tracer study Employability of Misamis Oriental State College of Agriculture and Technology (MOSCAT) Bachelor of Elementary Education (BEED) Graduates from SY 2008-2011 to gather profile and determine the employability percentage of MOSCAT BEED graduates, compare the employability percentage of LET and non-LET passers, find out if there is a significant relationship between the LET result and employability of graduates as well as the Program Curriculum obtained to the employability of its graduates. The study revealed that LET passers have a higher percentage of employment than non-LET passers and that there is a significant relationship between employability of MOSCAT BEED graduates to the degree finished. The results of the study provided baseline information to process evaluation on the performance of MOSCAT BEED graduates which can be very useful for any institutional planning and policy making in the future.

Padilla 2011 conducted a survey on the Technological Institute of the Philippines (TIP) conducted a survey targeting graduates of TIP-Manila from 2000-2004. The findings provided insights for institutional analysis of the factors determining employability, the competencies / skills that should be developed, the hiring rates of graduates of various programs and identification of the most responsive or in demand course based on job waiting time of graduates.

Inspired by the various success stories of tracer studies as tool for generating bases for curriculum development and policy direction, the researcher took on the challenge of doing the same in the local front. This study delved into the professional standing of the alumni of the University of Bohol Teachers College from school year 2009 to 2012 in the hope of unearthing employability-related issues and proposing improvement measures for the curriculum and program of the said department. 
The primary purpose of this study is to track and evaluate the professional standing of the alumni of the University of Bohol Bachelor in Elementary Education from school year 2009 to 2012 in the hope of coming up with a proposed enhancement measure for the curriculum and program of the said department. Specifically, it seeks to answer the following:

1. What is the profile of the respondents in terms of:

1.1 Personal

1.1.1 Age

1.1.2 Sex

1.1.3 Civil Status

1.2 Educational

1.2.1. Course

1.2.2. Major

1.2.3. Year Graduated

1.2.4. Academic Performance

1.2.5. Scholastic Merits

1.2.6. Preparation for Licensure Examination

1.3 Professional Standing

1.3.1 Eligibility

1.3.2 Employment

1.3.3 Types of Employment

1.3.4 Position Held

1.3.5 Means of Finding the Job

1.3.6 Length of time in finding the first job

1.3.7 Employment related to degree completed

2. To what extent the following areas are perceived important for career success by the alumni -respondents:

2.1 Personal skills

2.2 Interpersonal skills

2.3 Intellectual skills

2.4 Specific skills

3. To what extent do the alumni- respondents perceive that they possess the following categories of skills and competencies:

3.1 Personal skills

3.2 Interpersonal skills

3.3 Intellectual skills

3.4 Specific skills 
4. To what extent do the alumni respondents perceive the usefulness of the curriculum in their professional career?

It foresees that the outcome of this study will broaden the understanding of the students, alumni graduate and academic community on the rapid and constant change in the synergy between course structures and the working world, thereby preparing teaching professionals to meet the actual demands of the real work market.

It looks forward that this study could provide information for reflection among Boholano planners and program implementors to enhance existing programs and services to address the labor-mismatch problem in the local level.

Lastly, it aspires that the findings of this study will provide insights for government and non-government agencies in refining their poverty reduction and sustainable economic development agenda so that there would be increased decent and productive employment and job opportunities for all Filipino people, especially the young teaching professionals.

\section{METHODOLOGY}

The study used the descriptive, purposive method with the aid of a surveyquestionnaire adopted from an Employers Survey by Mahsood Shah in the University of Western Sydney with the author's full consent. This data-gathering tool was utilized to trace the professional standing of alumni respondents. The researcher also made use of documentary analysis on the academic performance and results on LET of the alumni-respondents.

The locale of the study was the University of Bohol (UB), a local college established in 1946 which has grown into a premier university in the Visayas region, catering to more than 6000 students enrolled in pre-elementary, basic education, short-term course, undergraduate, graduate and postgraduate degrees.

The respondents were the one hundred fifty one (151) graduates of Bachelor in Elementary Education (BEED) of the University of Bohol Teachers College from school year 2009 to 2012. The reason for the time frame is because said graduates were the ones most affected by the implementation of the Department of Education's Revised Guidelines on the Recruitment, Evaluation and Hiring of Teacher Applicants.

The instrument was divided into three parts: personal information, education and professional standing. It also included a checklist containing skills and 
competencies which respondents were asked to rate as to perceived extent of importance to career success and extent to which one possesses them. Another checklist had a list of curriculum content which the respondent was to rate according to perceived importance to career development, as well.

To ensure ease in answering, the questionnaire made use of open questions where the respondents were to supply the information called for and checklist form in which the respondents were to check their responses from a set of alternatives or specify the responses to the following scales:

\begin{tabular}{|l|l|l|}
\hline Description & Meaning & Weight Equivalent \\
\hline Extremely Important & Firmly accede with the statement & 4 \\
\hline Moderately Important & Accede with the statement & 3 \\
\hline Slightly Important & Slightly accede with the statement & 2 \\
\hline Not Important & Dissent with the statement & 1 \\
\hline
\end{tabular}

\begin{tabular}{|l|l|l|}
\hline Description & Meaning & Weight Equivalent \\
\hline Excellent & Firmly accede with the statement & 4 \\
\hline Very Good & Accede with the statement & 3 \\
\hline Good & Slightly accede with the statement & 2 \\
\hline Poor & Dissent with the statement & 1 \\
\hline
\end{tabular}

\begin{tabular}{|l|l|l|}
\hline Description & Meaning & Weight Equivalent \\
\hline Very Useful & Firmly accede with the statement & 4 \\
\hline Useful & Accede with the statement & 3 \\
\hline Less Useful & Slightly accede with the statement & 2 \\
\hline Not Useful & Dissent with the statement & 1 \\
\hline
\end{tabular}

For purposes of corroborating findings, the researcher will conduct document analysis using the Professional Regulation Commission Licensure Examination for Teachers results from 2009 to 2013.

This research study was a collaborative work with the UB Research Office, thus the participation of the said office cannot be overemphasized. A bulk of the preliminary activities was done by the said office. This included securing permission for the conduct of the study from the Vice President for Academic Affairs who approved and endorsed the research undertaking and securing a list of alumni graduates and their corresponding grade point average (GPA) from the Office of the University Registrar. 
The research classes of the UB Teachers College were tapped as enumerators to aid in data collection. The students distributed the questionnaires thru personal contact, email, snail mail and the social media. After the copies were retrieved, responses were collated, coded, encoded in the computer for electronic filtering and tabulated.

The data gathered through tracer survey questionnaire was beefed up through data mining on the Results of the Licensure Examination for Teachers from 2009 to 2012. Their responses were summarized and analyzed according to the purpose of the study.

\section{RESULTS AND DISCUSSION}

Table 1. Distribution of cases.

\begin{tabular}{|l|c|c|c|}
\hline \multirow{2}{*}{$\begin{array}{c}\text { Year } \\
\text { Graduated }\end{array}$} & \multicolumn{3}{|c|}{ Questionnaires } \\
\cline { 2 - 4 } & Distributed & Retrieved & Percent \\
\hline 2009 & 41 & 19 & $46.34 \%$ \\
\hline 2010 & 38 & 16 & $42.10 \%$ \\
\hline 2011 & 37 & 21 & $56.76 \%$ \\
\hline 2012 & 35 & 24 & $68.57 \%$ \\
\hline Total & $\mathbf{1 5 1}$ & $\mathbf{8 0}$ & $\mathbf{5 2 . 9 8 \%}$ \\
\hline
\end{tabular}

The distribution of respondents, as reflected in Table 1, has shown that out of the one hundred fifty one tracer survey forms distributed to the graduates of the University of Bohol Bachelor in Elementary Education from 2009 to 2012, only about half were returned.

Despite follow-up attempts through phone calls and chat messages by the research team, several respondents begged to be excluded from the study, the most popular excuses being: 1) "wala pa man mi ikapanghambog" (we have not yet accomplished anything noteworthy); 2) "unya nag mahuman na ug re-take, ma'am" (maybe after I successfully retake the licensure examination...); and 3) "wala man ko na-rank" (I have not been considered for ranking in the public school).

This limitation is consistent with obstacles raised in most tracer studies. Heidemann (2011) actually conducted a study entitled "Only Successful Graduates Respond to Tracer Studies: A Myth?" to ascertain if there is truth to it. Although his attempt has not been able to either confirm or bust the myth, the fact remains that there is always talks about the "continuum of resistance" when tracer studies are undertaken. 
Table 2. Profile of Respondents

\begin{tabular}{|c|c|c|}
\hline \multicolumn{3}{|l|}{$N=80$} \\
\hline \multicolumn{3}{|l|}{ PERSONAL } \\
\hline ITEM & $\mathrm{F}$ & $\%$ \\
\hline \multicolumn{3}{|l|}{ Age } \\
\hline 20 and below & 0 & $0.00 \%$ \\
\hline $21-25$ & 65 & $81.25 \%$ \\
\hline $26-30$ & 14 & $17.50 \%$ \\
\hline 31 and above & 1 & $1.25 \%$ \\
\hline TOTAL & 80 & $100.00 \%$ \\
\hline \multicolumn{3}{|l|}{ Sex } \\
\hline Female & 71 & $88.75 \%$ \\
\hline Male & 9 & $11.25 \%$ \\
\hline TOTAL & 80 & $100.00 \%$ \\
\hline \multicolumn{3}{|l|}{ Civil Status } \\
\hline Single & 74 & $92.50 \%$ \\
\hline Married & 6 & $7.50 \%$ \\
\hline Living-In & 0 & $0.00 \%$ \\
\hline Separated & 0 & $0.00 \%$ \\
\hline Widow & 0 & $0.00 \%$ \\
\hline TOTAL & 80 & $100.00 \%$ \\
\hline \multicolumn{3}{|l|}{ EDUCATIONAL } \\
\hline \multicolumn{3}{|l|}{ Course } \\
\hline BEED & 80 & $100.00 \%$ \\
\hline Others & 0 & $0.00 \%$ \\
\hline TOTAL & 80 & $100.00 \%$ \\
\hline \multicolumn{3}{|l|}{ Major } \\
\hline Gen Ed & 51 & $63.75 \%$ \\
\hline SPED & 13 & $16.25 \%$ \\
\hline Others & 16 & $20.00 \%$ \\
\hline TOTAL & 80 & $100.00 \%$ \\
\hline \multicolumn{3}{|l|}{ Year Graduated } \\
\hline 2009 & 19 & $23.75 \%$ \\
\hline 2010 & 16 & $20.00 \%$ \\
\hline 2011 & 21 & $26.25 \%$ \\
\hline 2012 & 24 & $30.00 \%$ \\
\hline TOTAL & 80 & $100.00 \%$ \\
\hline
\end{tabular}


Table 2 presents the profile of respondents as to age, sex, civil status, course enrolled, major, year graduated. Out of the eighty participants, majority (65 or $81.25 \%$ ) were between ages $21-25$, fourteen (17.50\%) were between $26-30$ years old while one (1.25\%) was over 31 years old. About nine out of every ten respondents (88.75\%) were female. Overall, only nine $(11.25 \%)$ were males. Seventy four $(92.50 \%)$ of the respondents were single while six $(7.50 \%)$ were married. All of them completed Bachelor in Elementary Education with 63.75\% majoring in General Education, $16.25 \%$ in Special Education and $20.00 \%$ in different majors from the old curriculum. Each graduating class was well represented with twenty four (30\%) from batch 2012, twenty-one (26.25\%) from batch 2011, nineteen (23.75\%) from batch 2009 and sixteen (20.00\%) from batch 2010.

Acquiring profile data served as basis of understanding pertaining to the socio-demographic characteristics of the respondents. A research reported that academic exposure and competency were fundamentals of a person's employability. (Nilsson \& Ekberg, 2012)

Table 3. Academic Performance, Scholastic Merits and Preparation for LET $\mathrm{N}=80$

\begin{tabular}{|l|l|l|}
\hline Academic Performance & F & $\%$ \\
\hline Excellent & 8 & $10.00 \%$ \\
\hline Very Good & 45 & $56.25 \%$ \\
\hline Good & 26 & $32.50 \%$ \\
\hline Fair & 1 & $1.25 \%$ \\
\hline TOTAL & $\mathbf{8 0}$ & $\mathbf{1 0 0 . 0 0 \%}$ \\
\hline Scholastic Merits (Scholarship) & & \\
\hline Scholarship Recipient & 22 & $27.50 \%$ \\
\hline No Scholarship & 58 & $72.50 \%$ \\
\hline TOTAL & $\mathbf{8 0}$ & $\mathbf{1 0 0 . 0 0 \%}$ \\
\hline Scholastic Merits (Honors upon Graduation) & & \\
\hline Honor Graduates & 5 & $6.25 \%$ \\
\hline None Honor & 75 & $93.75 \%$ \\
\hline TOTAL & $\mathbf{8 0}$ & $\mathbf{1 0 0 . 0 0 \%}$ \\
\hline Preparation for LET & & \\
\hline Both Review Class and Refresher & 34 & $42.50 \%$ \\
\hline Review Class & 14 & $17.50 \%$ \\
\hline Refresher & 15 & $18.75 \%$ \\
\hline Self Review & 17 & $21.25 \%$ \\
\hline TOTAL & $\mathbf{8 0}$ & $\mathbf{1 0 0 . 0 0 \%}$ \\
\hline & & \\
\hline
\end{tabular}


Table 3 encapsulates the academic performance, scholastic merits and preparation for the Licensure Examination for Teachers (LET) of the alumni respondents.

Academic performance. A generated report from the University Management Information System revealed that forty-five (56.25\%) had a grade point average (GPA) equivalent to Very Good, twenty six (32.50\%) equivalent to Good, eight (10.00\%) equivalent to Excellent and one (1.25\%) equivalent to Fair.

This agrees with the study of Pan et al., 2011 stating that employability proficiency are essentially linked with the academic performance of the graduate students which includes excellent English communication skills, IT literacy, theory application, steadiness and ability to handle pressure at work.

Scholastic Merits. Of the eighty alumni respondents, only twenty two (27.50\%) were recipients of scholarships, broken down as follows: twelve (54\%) under the Work Scholars Program, seven (32\%) under the Academic Scholarship Program and the remaining three (14\%) under a Government-sponsored scholarship program. Furthermore, five (22.73\%) of the twenty two scholars graduated with honors. The findings agrees with Gaskel et al. (2004) statement that the academe and training can be seen as a way of preparing a person to manage their undertaking. He also added that formal training and exposure thru education gives an individual a wide opportunity of acquiring an employment.

Preparation for the Licensure Examination for Teachers (LET). Two out of ten $(21.25 \%)$ relied purely on self review, the others have done extra measures to ensure positive outcome of the test, as follows: thirty-four (42.50\%) enrolled in both Review and Refresher Classes, fifteen (18.75\%) on Refresher Class alone and fourteen (17.50\%) on Review class alone.

Table 4. Eligibility and Employment Status of Respondents $\mathrm{N}=80$

\begin{tabular}{|l|l|l|}
\hline \multicolumn{1}{|c|}{ Eligibility } & \multicolumn{1}{c|}{ F } & \multicolumn{1}{c|}{$\%$} \\
\hline Sub Prof & 0 & $0.00 \%$ \\
\hline Prof and LET & 10 & $12.50 \%$ \\
\hline LET & 52 & $65.00 \%$ \\
\hline None & 18 & $22.50 \%$ \\
\hline TOTAL & $\mathbf{8 0}$ & $\mathbf{1 0 0 . 0 0 \%}$ \\
\hline Employed/Unemployed & & \\
\hline Employed & 71 & $88.75 \%$ \\
\hline Self-Employed & 1 & $1.25 \%$ \\
\hline Unemployed & 8 & $10.00 \%$ \\
\hline TOTAL & $\mathbf{8 0}$ & $\mathbf{1 0 0 . 0 0 \%}$ \\
\hline
\end{tabular}


Table 4 reflects the eligibility and employment status of the respondents. Fifty two (65\%) were LET passers while ten (12.50\%) had both professional and LET eligibilities. The remaining eighteen (22.50\%) were not eligible.

The eligibility status presented in the table coincides with Salinas and Nillama (2011) tracer study on Employability of Misamis Oriental State College of Agriculture and technology with BEED graduates from SY 2008-2011 as respondents. Findings of the study revealed that LET passers possessed higher opportunity for job employments than non-LET passers. Also, the results of the study indicated that there was a significant relationship between the employability of the respondents to the degree finished.

Employment Status. Seventy one (88.75\%) of the respondents were employed while one (1.25\%) was an employer. Although majority were working, one out of every ten $(10.00 \%)$ of the alumni were unemployed.

The employment status entailed in this study matched with the tracer study of Science and Technology graduates of 2000 and 2001 in Sri Lanka. The main objective of the study was to gain data specifically on the present status of employment, its sector, absorption patterns and rates into the labor market and other valuable issues. The outcome of the study was utilized for the evaluation of degree course to attain the basic requirements of the industry for employment (Pathriage et al, 2003).

Table 5. Professional Standing of Employed Respondents

$\mathrm{N}=72$

\begin{tabular}{|l|l|l|}
\hline Type of Employment & F & $\%$ \\
\hline Government & 27 & $37.50 \%$ \\
\hline Non-Government Organization & 1 & $1.39 \%$ \\
\hline Private & 44 & $61.11 \%$ \\
\hline TOTAL & 72 & $100.00 \%$ \\
\hline Positions Held & & \\
\hline Managerial & 1 & $1.39 \%$ \\
\hline Junior Officer & 2 & $2.78 \%$ \\
\hline Administrative Officer & 5 & $6.94 \%$ \\
\hline Rank and File & 2 & $2.78 \%$ \\
\hline Head Teacher & 2 & $2.78 \%$ \\
\hline Teacher 1 & 46 & $63.89 \%$ \\
\hline Au Pair & 1 & $1.39 \%$ \\
\hline Clerical & 6 & $8.33 \%$ \\
\hline Customer Associate & 2 & $2.78 \%$ \\
\hline Fireman & 1 & $1.39 \%$ \\
\hline
\end{tabular}




\begin{tabular}{|l|l|l|}
\hline Nurse & 1 & $1.39 \%$ \\
\hline Sales Associate & 3 & $4.17 \%$ \\
\hline TOTAL & 72 & $100.00 \%$ \\
\hline Means of Finding Job & & \\
\hline Job fairs & 2 & $2.78 \%$ \\
\hline Surfed online for job advertisements & 4 & $5.56 \%$ \\
\hline Information from relatives and friends & 55 & $76.39 \%$ \\
\hline DepEd information on teaching vacancies & 3 & $4.17 \%$ \\
\hline An employer contacted me & 7 & $9.72 \%$ \\
\hline Started own business & 1 & $1.39 \%$ \\
\hline TOTAL & 72 & $100.00 \%$ \\
\hline Length of Time in Finding First Job & & \\
\hline Right after graduation & 20 & $27.78 \%$ \\
\hline 3-6 months & 23 & $31.94 \%$ \\
\hline 7-9 months & 11 & $15.28 \%$ \\
\hline 10 months to one year & 10 & $13.89 \%$ \\
\hline More than one year & 8 & $11.11 \%$ \\
\hline TOTAL & 72 & $100.00 \%$ \\
\hline Employment Related To Degree & & \\
\hline Related since then & 48 & $66.67 \%$ \\
\hline Not related since then & 20 & $27.78 \%$ \\
\hline Yes, its related before, now not anymore & 3 & $4.17 \%$ \\
\hline Not related before but now its related & 1 & $1.39 \%$ \\
\hline TOTAL & 72 & $100.00 \%$ \\
\hline
\end{tabular}

Table 5 presents an overview of the professional standing of the employed respondents in terms of type of employment, positions held, means of finding a job, length of time in finding first job and relevance of employment to the degree finished.

As to type of employment, forty-four (61.11\%) of the respondents belonged to the private sector, twenty-seven (37.50\%) were from the government sector, while one (1.39\%) came from a non-government organization.

Among the government employees, nineteen (70.37\%) worked at the Department of Education. The seventy two alumni employer/employees were broken down as follows: Forty-six teachers (63.89\%), six clerks (8.33\%), five administrative officers (6.94\%), three sales associates (4.17\%), two head teachers $(2.78 \%)$, two junior officers $(2.78 \%)$, two rank and file $(2.78 \%)$, two customer associates $(2.78 \%)$, one manager $(1.39 \%)$, one au pair $(1.39 \%)$, one fireman (1.39\%) and one nurse(1.39\%). 
Fifty-five (76.39\%) of the alumni found their job through information given by a relative or friend, seven $(9.72 \%)$ claimed employers contacted them, four (5.56\%) surfed online for job advertisements, three $(4.17 \%)$ through DepEd information on teaching vacancies and two (2.78\%) through job fairs. One (1.39\%) divulged that when she could not find a job from anywhere, she decided to start her own business.

As to waiting time, (27.78\%), right after graduation; twenty-three alumni (31.94\%) answered 3-6 months; twenty eleven (15.28\%), 7-9 months; ten (13.89\%), 10 months to one year; and eight (11.11\%), more than one year. It showed that completing the course helped graduates find employment and passing the licensure examination assured greater employability.

Out of the seventy two respondents, forty-eight (66.67\%) said that their jobs were related to the degree they finished; twenty $(27.78 \%)$ claimed that it was not related; three $(4.17 \%)$ said that it was related before but not anymore; and one $(1.39 \%)$ said it was not related before but related now.

\section{Perceived Importance of Competencies and Skills for Career Success and Extent to which Graduates Possess Competencies and Skills}

For clarity of presentation, the gap between their perception of importance and the extent of possessing competencies and skills is presented in graphic form, as follows: Personal Skills in Figure 6; Interpersonal Skills in Figure 7, Intellectual Skills in Figure 8 and Specific Skills in Figure 9.

Under the Personal Skills area they varied in ranking those items. They placed Rank 1 the item on Wanting to produce as good a job as possible as to importance to career success, but surprisingly, a huge gap was observed because they put the same item on rank 7.5 as to the extent that they possess such skill. It was followed by Being willing to face and learn from errors and listen openly to feedback as rank 2.5 in terms of its importance of career success and it is in consonance with the extent to which they possess that skill (Rank 2). Rank 2.5 as well is the item on Understanding personal strengths \& limitations as to importance of career success and it ranked 3.5 as to the extent that they possess that skill. Being flexible and adaptable ranked 1 as the skills that the graduate respondents perceive to possess while it ranked 4.5 as to the importance of career success. Being willing to face and learn from errors and listen openly to feedback ranked 2 as to the skills that the graduate respondents perceive to possess and ranked 2.5 as to importance for this skill for career success. Understanding personal strengths \& limitations ranked 3.5 as to the extent that they perceive 
that they possess this skill and ranked 2.5 as to the extent of importance of this skill. Being able to remain calm under pressure or when things go wrong ranked 3.5 as how they perceived that they possess this skill but a big gap of 3.5 since it ranked 7 as to its importance for career success.

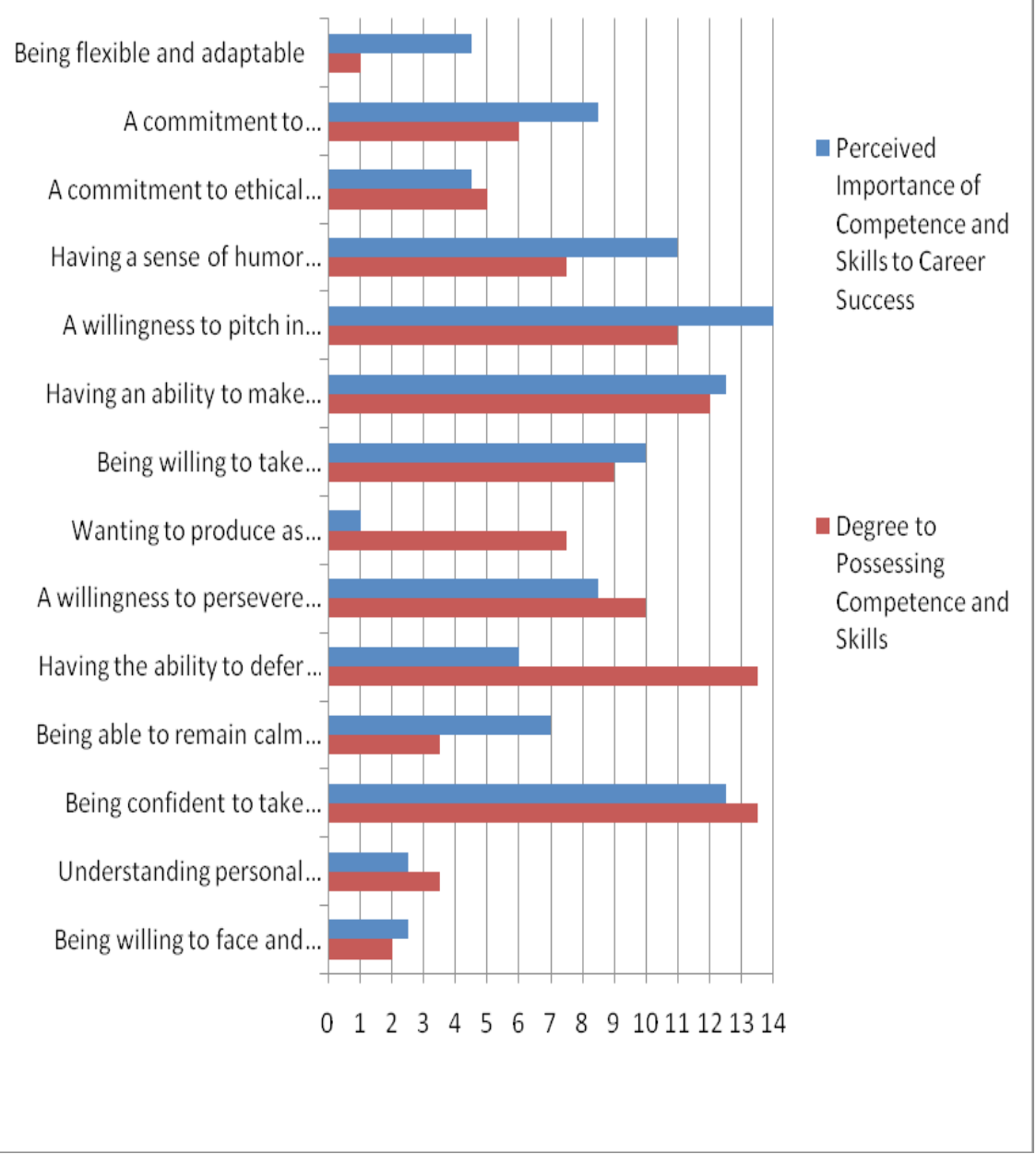

Figure 1. Gap Between Perceived Extent of Importance to Career Success and Degree of Possessing Personal Skills Among the Graduate Respondents 


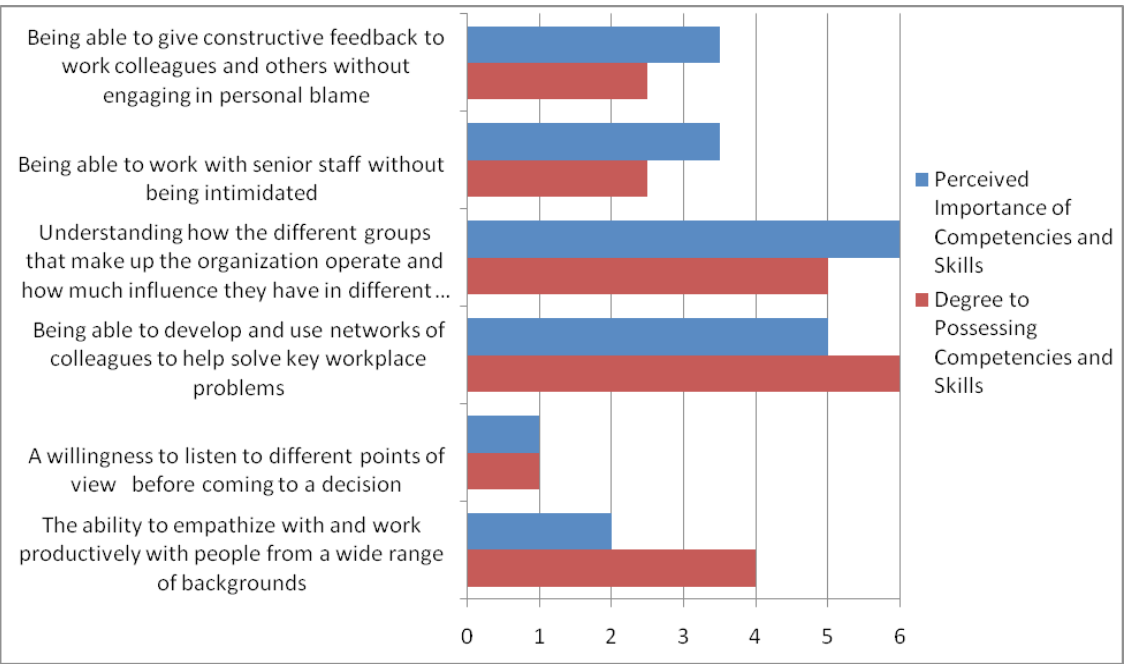

Figure 2. Gap Between Perceived Extent of Importance to Career Success and Degree of Possessing Interpersonal Skills Among the Graduate Respondents

With regards to Interpersonal Skill area, ranked highest on both the importance of career success and the extent to which they possess the skill is the item on willingness to listen to different points of view before coming to a decision. Ranked 2 as to the career success is the ability to empathize with and work productively with people from a wide range of backgrounds but it lagged a little behind the extent that they possess that skill because it ranked 4. Third in rank as to the extent that they possess the ability is Being able to work with senior staff without being intimidated (rank 3.5) and Being able to give constructive feedback to work colleagues and others without engaging in personal blame (ranked 3.5) which also has gotten a closer ranking of 2.5 as to the rankings in terms of in which the they possess those skills. 


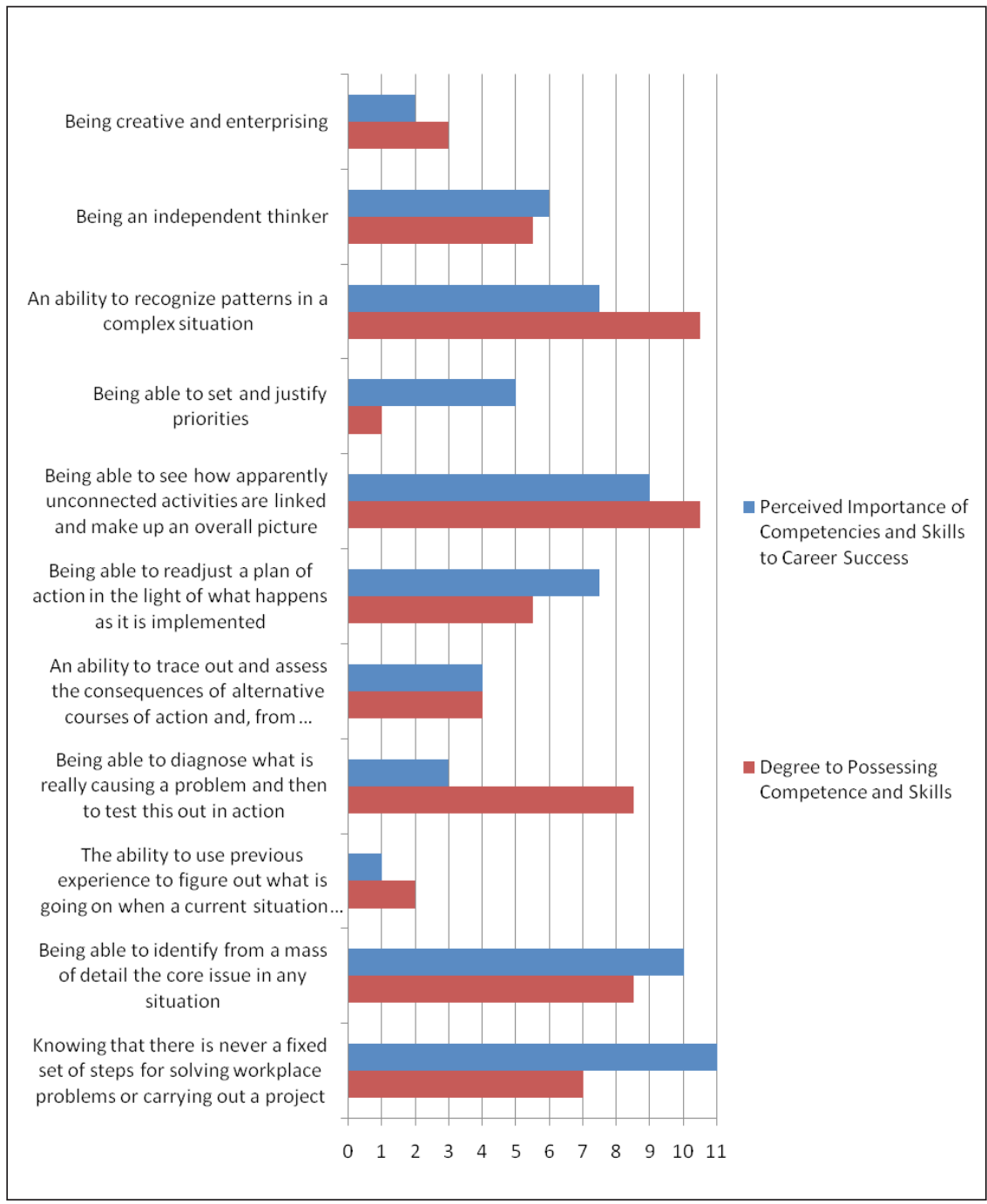

Figure 3. Gap Between Perceived Extent of Importance to Career Success and Degree of Possessing Intellectual Skills Among the Graduate Respondents 
In the Intellectual Skills area, ranked 1 as to the importance of career success is The ability to use previous experience to figure out what is going on when a current situation takes an unexpected turn and it was also ranked 2 as to the extent that they possess those skills. The disparity was clearly shown on item on Being able to diagnose what is really causing a problem and then to test this out in action which was ranked 3 as to its importance of career success but was being ranked 8.5 as to the extent that they possess the skill. Being able to set and justify priorities ranked 1 as to the extent that they possess the ability but it ranked 5 as to its degree of importance. Second in rank as to the extent that they possess the skill of The ability to use previous experience to figure out what is going on when a current situation takes an unexpected turn and it ranked 1 as to its importance to career success. Being creative and enterprising ranked $3^{\text {rd }}$ as how the graduate respondents perceive how they possess this skill and ranked $2^{\text {nd }}$ as to the degree of importance to career success.

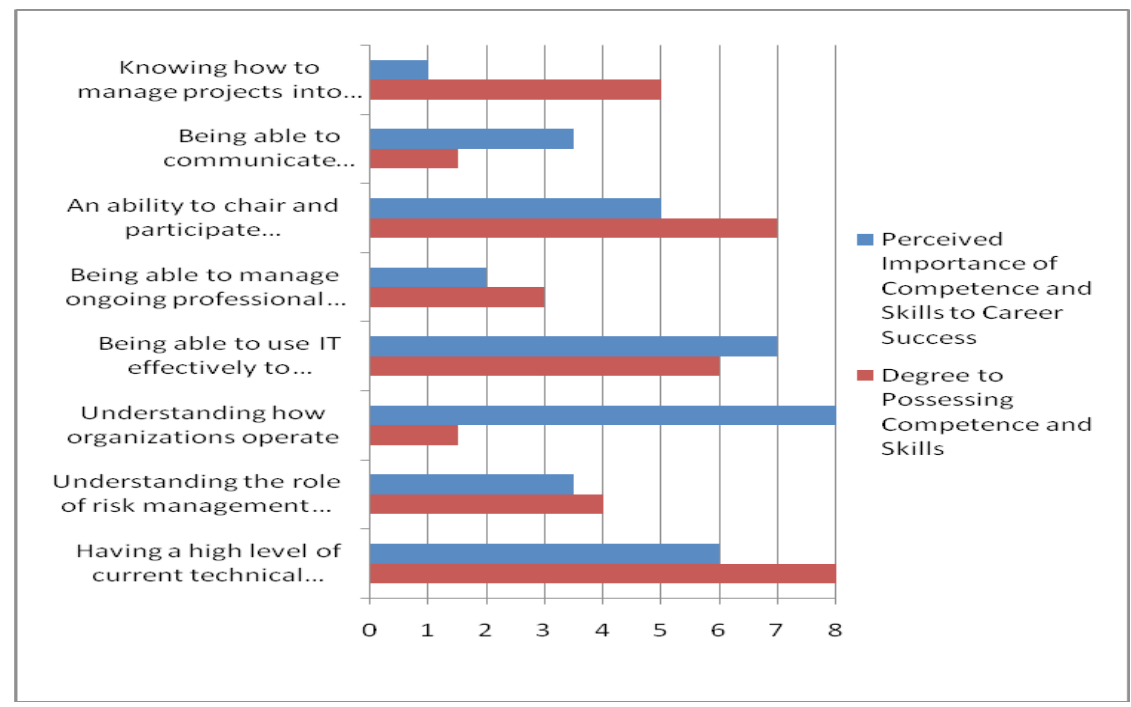

Figure 4. Gap Between Perceived Extent of Importance to Career Success and Degree of Possessing Specific Skills Among the Graduate Respondents

On the Specific Skill, the item on Knowing how to manage projects into successful implementation is ranked one as to the importance of career success but it was ranked 5 as to the extent that they possess the ability. Being creative and enterprising is ranked 2 nd as to the importance of career success 
but it ranked 3rd as to the extent that they possess those skills. The graduate respondents ranked 1.5 as to the extent they possess the skill on Understanding how organizations operate but the astonishing gap exists as to its degree of importance for career success because it is ranked 8th. They also ranked 1.5 as to they perceive to possess the skill on Being able to communicate effectively but they ranked it 3.5 as to its degree of importance to career success.

Table 6. Usefulness on the Curriculum as Perceived by Alumni Respondents $\mathrm{N}=80$

\begin{tabular}{|c|c|c|c|c|c|c|c|c|c|c|c|}
\hline \multirow{2}{*}{ Items } & \multicolumn{2}{|c|}{ VU (4) } & \multicolumn{2}{|c|}{$\mathrm{U}(3)$} & \multicolumn{2}{|c|}{ LU (2) } & \multicolumn{2}{|c|}{$\mathrm{NU}(1)$} & \multirow[t]{2}{*}{ WM } & \multirow[t]{2}{*}{ DV } & \multirow[t]{2}{*}{ Rank } \\
\hline & $\mathrm{F}$ & WV & $\mathrm{F}$ & WV & $\mathrm{F}$ & WV & $\mathrm{F}$ & WV & & & \\
\hline General Education & 48 & 192 & 31 & 93 & 1 & 2 & 0 & 0 & 3.59 & VU & 3 \\
\hline Non Credit & 19 & 76 & 49 & 147 & 12 & 24 & 0 & 0 & 3.09 & $U$ & 4 \\
\hline Professional Courses & 54 & 216 & 25 & 75 & 1 & 2 & 0 & 0 & 3.66 & VU & 1 \\
\hline Major Subjects & 52 & 208 & 27 & 81 & 0 & 0 & 1 & 1 & 3.63 & VU & 2 \\
\hline Composite mean & & & & & & & & & 3.49 & VU & \\
\hline
\end{tabular}

Legend:
1-1.74
Not Useful (NU)
$1.75-2.49$
Less Useful (LU)
2.50-3.24
Useful (U)
$3.25-4.0$
Very Useful (VU)

\section{CONCLUSIONS}

Based on the findings, the following conclusions were drawn:

1. Majority of the respondents had Very Good rating as to academic performance and majority of them also passed the LET. Majority was employed related to their degree completed and most of them obtained the entry level of teaching position (Teacher 1). As to length of time in finding jobs, there was a spread, right after graduation, and three to six months after graduation.

2. As to personal skills, interpersonal (that included communication skills), intellectual and specific skills areas, the graduate-respondents rated all items as Extremely Important (EI), as to its importance to career success and they rated the same items as Very Good (VG) as to the extent they 
possessed such skills. Those skills were clearly undergone in their stay at the university.

3. As to the usefulness of the curriculum, the graduate- respondents found most of the subjects offered very useful.

\section{LITERATURE CITED}

Altbach, P. G., Reisberg, L., \& Rumbley, L. E. (2009). Trends in global higher education: Tracking an academic revolution. Retrieved from http://goo. gl/23s8Lp (Accessed last November 30, 2013).

Brinton, M. C. (2000). Social capital in the Japanese youth labor market: Labor market policy, schools, and norms. Policy Sciences, 33(3-4), 289-306. Retrieved from http://goo.gl/MTwN84 (Accessed last November 28, 2013).

Dacre-Pool, L. Moving from conceptual ambiguity to operational clarity: Employability, enterprise and entrepreneurship in higher education, Education and Training, 52, 1, 89-94, 2010.

Dacre-Pool, L. The key to employability: developing a practical model of graduate employability, Education and Training. 49, 4, 277-289, 2007.

Defensor, N. Quality assurance in Southeast Asia : The Philippine experience. SEAMEO RIHED Back to Back Conference on Quality Assurance in Southeast Asian Countries, Bangkok, Thailand, 2010.

Gaskell, J., Rubenson, K. (2004). Towards a research program in education and training. Retrieved from http://goo.gl/0tIRnM (Accessed last July 13, 2013).

Heidemann, L. (2011). ALMALAUREA WORKING PAPERS no. 13. Retrieved from http://goo.gl/hR3Brl (accessed last November 30, 2013.)

Nilsson, S., Ekberg, K. (2012). Employability and work ability: returning to the labour market after long-term absence. Work: A journal of prevention, assessment and rehabilitation. Retrieved from http://goo.gl/HzYdwn (accessed last July 15, 2013) 
Olaniyan, D. A., \& Okemakinde, T. (2008). Human capital theory: Implications for educational development. Pakistan Journal of Social Sciences, 5(5), 479483. Retrived from http://goo.gl/GM8dya (Accessed last 30 November, 2013).

Padilla, J. N. (2011). Graduate Tracer Study of TIP Manila Graduates, SY 20002001 to SY 2003-2004. TIP-Manila Research Journal, 5(1). Retrieved from http://goo.gl/nzTSOJ (accessed last November 30, 2013).

Pan, Y.J., Lee, L.S. (2011). Academic Performance and Perceived Employability of Graduate Students in Business and Management - An Analysis of Nationwide Graduate Destination Survey. Vol 25 pp 91-103. Retrieved from http://goo.gl/ATBgPI (Accessed last July 13, 2013).

Parks-Yancy, R. (2006). The effects of social group membership and social capital resources on careers. Journal of Black Studies, 36(4), 515-545. Retrieved from http://goo.gl/WvNOUb (Accessed last November 30, 2013).

Pathirage, R. P., Dilrukshi, P. R. M. P., \& Hettiarachchi, A. P. (2003). Tracer study of science and technology ( $\mathrm{S}$ and $\mathrm{T}$ ) graduates passed out from universities in Sri Lanka (2000/2001). Nafional Science Foundation of Sri Lanka, Colombo, 55. Retrieved from http://goo.gl/bwdxwV, (Accessed last November 30, 2013).

Pegg, A., Waldock, J., Hendy-Isaac, S., \& Lawton, R. (2012). Pedagogy for employability. Retrieved from http://goo.gl/qieFuh, (Accessed last November 29, 2013).

Quiggin, J. (1999). Human capital theory and education policy in Australia. Australian Economic Review, 32(2), 130-144. Retrieved from http://goo. $\mathrm{gl} / 9 \mathrm{mOlaO}$, (Accessed last 30 November, 2013).

UNESCO-IHE (2011). Institute for Water Education, an alumni tracer survey. Retrieved from http://goo.gl/avwKvX, (accessed last November 30, 2013). 
Tracer Atudy of AIT graduates (2003 to mid-2008), retrieved from http://goo.gl/ mhZQAs, (accessed last November 30, 2013).

Watts, A. G. (2006). Career development learning and employability. Heslington: Higher Education Academy. Retrieved from http://goo.gl/5wt4uw, (accessed last November 28, 2013).

Yorke, M. (2006). Employability in higher education: what it is, what it is not. 